\title{
PERANCANGAN SISTEM INFORMASI PENJUALAN DAN PEMBELIAN MOBIL PADA SALFA MOTOR
}

\author{
Azhar Rimawan Ilyas', Dian Novita ${ }^{2}$ \\ Program Studi Informatika, Fakultas Teknik dan Ilmu Komputer, Universitas Indraprasta PGRI \\ Jalan Raya Tengah No 80, Kelurahan Gedong, Pasar Rebo, Jakarta Timur \\ Azharrimawan240997@gmail.com ${ }^{1}$,Dyan.novita21@gmail.com²
}

\begin{abstract}
Abstrak
Tujuan Penelitian adalah untuk membuat model perancangan aplikasi penjualan dan pembelian mobil yang efisien dan dapat membantu kinerja karyawan saat transaksi penjualan dan pembelian mobil. Metode yang digunakan dalam penelitian ini adalah metode research and development yaitu proses dan langkah-langkah untuk mengembangkan suatu produk baru atau menyempurnakan produk yang telah ada dan dapat dipertanggung jawabkan. Peneliti menarik kesimpulan bahwa aplikasi yang telah dibangun dapat mempermudah karyawan dalam proses transaksi penjualan dan pembelian. Proses penjualan dan pembelian menjadi lebih efektif dan efisien serta data-data tersusun rapi dalam database.
\end{abstract}

Kata kunci: penjualan dan pembelian mobil, perancangan aplikasi, java

\begin{abstract}
The purpose of this research is to create an efficient model of car sales and purchase application design and can help employees perform when selling and purchasing cars. The method used $n$ this research is and development method that is the process and steps to develop a new product or perfect an existing and accountable product. The researchers draws the conclusion that the application that has been built can facilitate employees in the process of sales and purchase transactions. The sales and purchase process becomes more effective and efficient and the data is neatly arranged in the database.
\end{abstract}

Keyword: car sales and purchases, application design, java

\section{PENDAHULUAN}

Perkembangan teknologi informasi saat ini berkembang dengan pesat dan masuk kedalam berbagai aspek-aspek kehidupan. Sebagian besar masyarakat menggunakan teknologi sebagai penunjang kinerja dan produktivitasnya. Ini dikarenakan dapat mempermudah dan meringankan suatu pekerjaan dengan teknologi yang dimiliki oleh masing-masing perangkat sehingga membuat pekerjaan lebih cepat, efisien, dan terstruktur. Hal ini dapat dilihat semakin banyaknya pengguna yang menyimpan dan mengolah datanya menggunakan komputer yang mana jumlah penggunanya bertambah setiap tahun terutama di negara berkembang seperti Indonesia. Meskipun di Indonesia perkembangan teknologi masih tahap awal pengembangan, namun jika dilihat dari jumlah penduduk serta jumlah usia produktif yang ada maka dapat dilihat bahwa peluang yang ada di Indonesia cukup menjanjikan. Perkembangan teknologi di Indonesia juga merubah cara pandang seseorang dalam berbisnis. Maka dari itu banyak perusahaan kecil maupun menengah yang mencoba untuk memanfaatkan perkembangan teknologi.

Salfa Motor merupakan salah satu usaha yang bergerak dalam bidang penjualan dan pembelian mobil. Namun pada proses pengolahan data penjualan dan pembelian masih dilakukan secara manual.

Usaha ini masih memiliki kendala dalam pengolahan data yang masih menggunakan buku. Selain itu penyimpanan data-data yang semakin banyak, mengakibatkan terjadinya penumpukan yang tidak beraturan yang dapat terjadinya kehilangan ataupun tertukarnya data.

Menurut (Yunaestri, 2011), "Sistem adalah sekelompok elemen-elemenyang terintegrasi dengan tujuan yang sama untuk mencapai tujuan".

(Alamsyah, 2011), "Sistem Informasi adalah sebuah sistem manusia; mesin yang terpadu, untuk menyajikan informasi guna mendukung fungsi operasi, manajemen, dan pengambilan keputusan dalam sebuah organisasi”". 
Oleh karena itu penerapan sistem informasi yang terkomputerisasi sangat diperlukan. Usaha ini memerlukan suatu sistem yang dapat mengelola segala aktifitas jual beli yang terkomputerisasi sehingga dapat memudahkan pendataan dan transaksi yang terjadi. Selain itu sistem dapat mengelola aktifitas jual beli pada tempat tersebut, dan dapat memudahkan bagi karyawan dalam melakukan pendataan ataupun transaksi kepada pelanggan.

\section{PENELITIAN RELEVAN}

Penelitian oleh (Deddy \& Sherin, 2017) yang berjudul Perancangan Sistem Informasi Penjualan Mobil di Dealer Lung Ma Motor. Metodologi penelitian yang digunakan adalah Unified Approach $(U A)$, hasil dari penelitian ini adalah rancangan sistem informasi penjualan mobil pada dealer lung ma motor yang dapat membantu proses penginpuan data menjadi lebih cepat, mudah, dan akurat serta meminimalisir kesalahan dalam proses pengolahan data.

Penelitian oleh (Februariyanti, 2012) yang berjudul Rancang Bangun Sistem Perpustakaan untuk Jurnal Elektronik. Metodologi penelitian yang digunakan adalah observasi serta studi pustaka, hasil dari penelitian ini adalah rancangan sistem perpustakaan digital untuk mengelola koleksi jurnal.

\section{METODE PENELITIAN}

Metode penelitian yang digunakan adalah metode research and development, yaitu proses dan langkah-langkah untuk mengembangkan suatu produk baru atau menyempurnakan produk yang telah ada dan dapat dipertanggung jawabkan. Produk tersebut dapat berupa perangkat keras ataupun perangkat lunak. Serta metode pengumpulan data yang digunakan peneliti adalah observasi, studi pustaka, serta wawancara.

\section{HASIL DAN PEMBAHASAN}

Berikut ini merupakan penggambaran tentang sistem yang diusulkan pada pengolahan data Salfa Motor secara keseluruhan dalam bentuk diagram konteks.

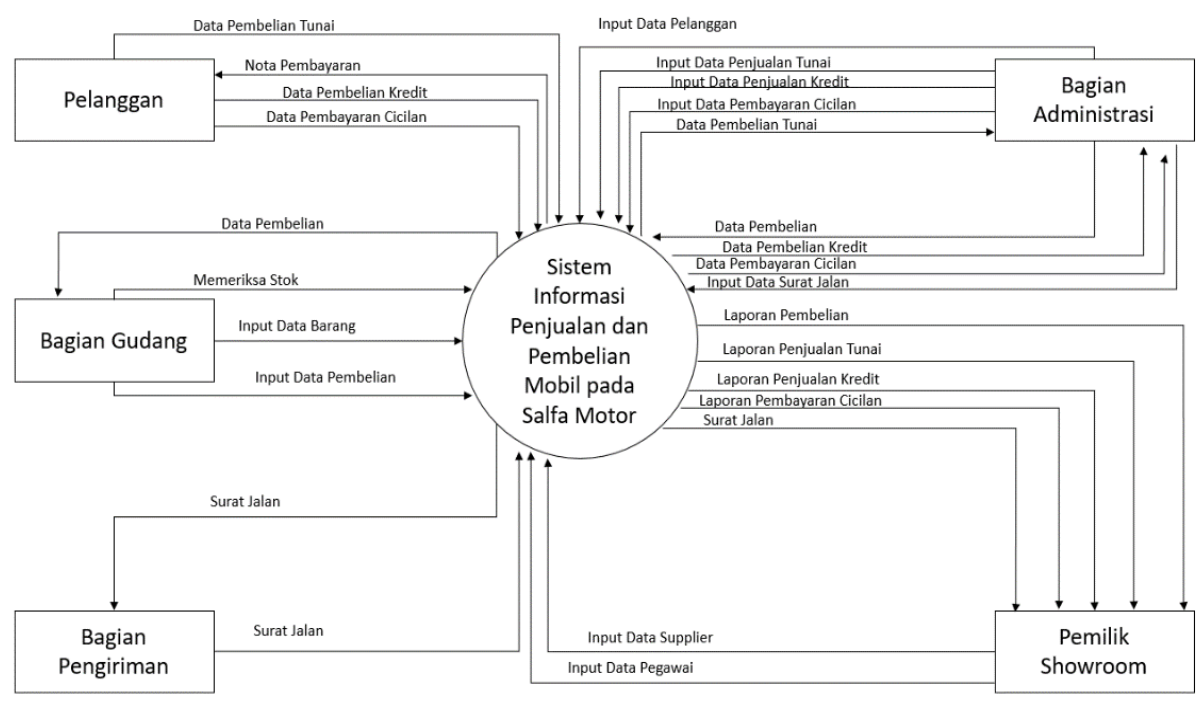

Gambar 1. Diagram Konteks Sistem Salfa Motor

Selanjutnya penulis membuat aplikasi dengan menggunakan Java berbasis desktop dan database mysql. Berikut ini adalah tampilan dari aplikasi penjualan dan pembelian mobil Salfa Motor. 


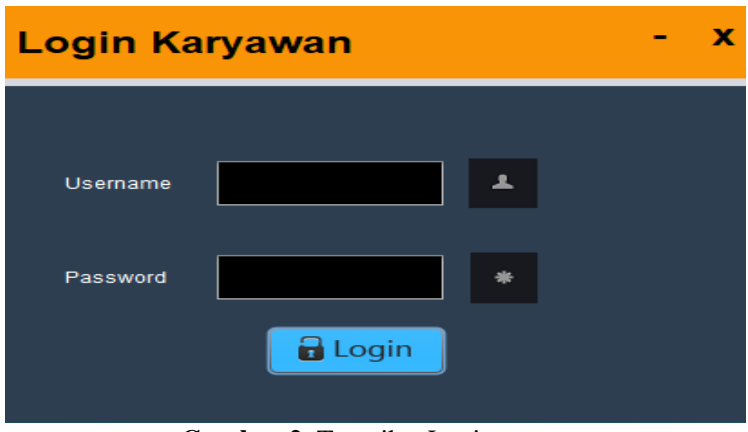

Gambar 2. Tampilan Login

Tampilan ini terdapat pada awal program. Menu login digunakan sebagai kata kunci sebelum kita memasuki menu utama. Agar tidak disalah gunakan oleh oknum yangtidak bertanggung jawab.

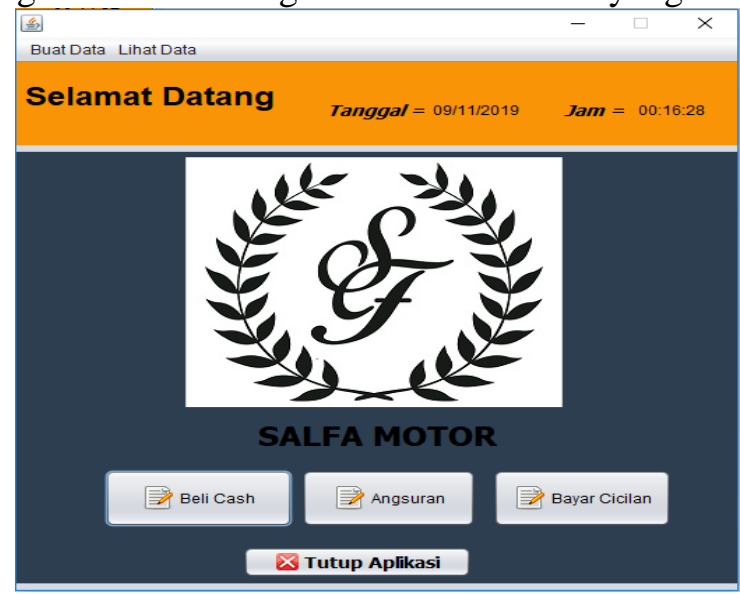

Gambar 3. Tampilan Menu Utama

Tampilan ini adalah menu penjualan dan pembelian. Pada layar utama tersedia menu bar yang tediri dari Buat data dan Lihat Data. Pada menu buat data terdiri dari data mobil, data pelanggan, data karyawan, dan data surat jalan. Sedangkan pada menu lihat data terdiri dari daftar data mobil, daftar data transaksi cash, daftar data kredit, dan daftar data pembayaran cicilan. Pada tampilan ini terdapat empat button, yaitu Beli Cash yang digunakan untuk melakukan penjualan secara tunai, Angsuran yang digunakan untuk melakukan penjualan secara kredit, Bayar Cicilan yang digunakan untuk pembayaran cicilan, dan Tutup Aplikasi yang digunakan untuk menutup jendela aplikasi.

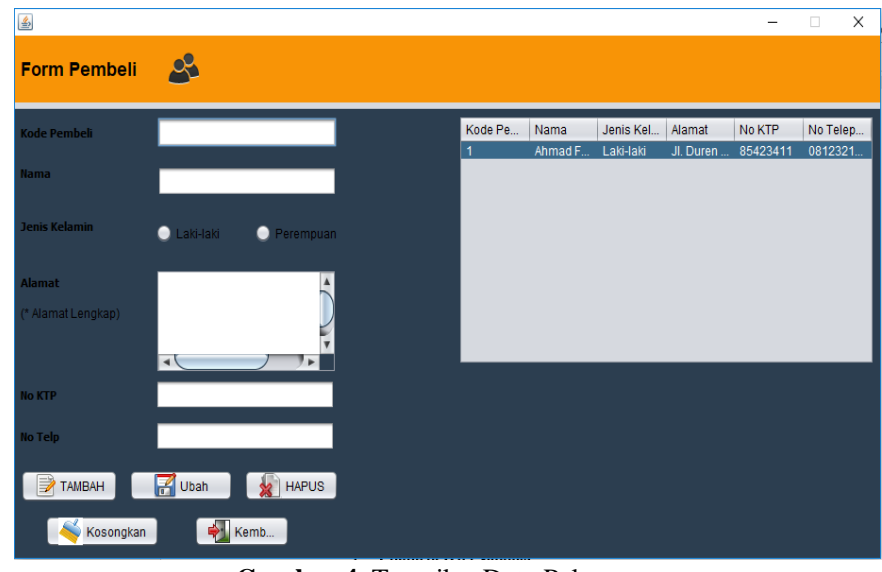

Gambar 4. Tampilan Data Pelanggan

Pada form ini bagian administrasi menginput data pembeli secara lengkap untuk bisa melanjutkan ke proses penjualan tunai, penjualan kredit, dan pembayaran cicilan. 


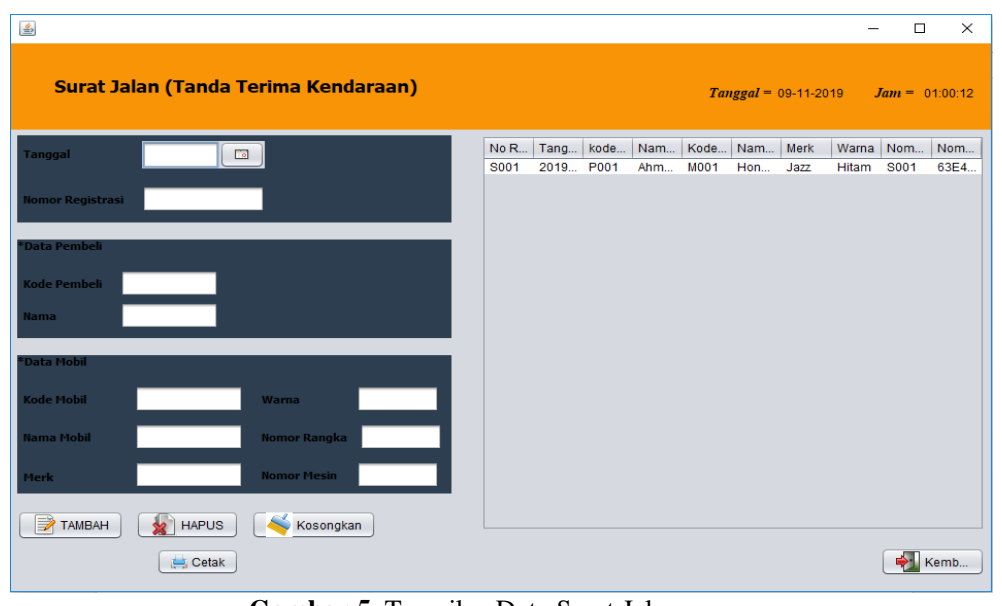

Gambar 5. Tampilan Data Surat Jalan

Pada form ini bagian administrasi menginput data surat jalan dan mencetak laporan surat jalan.

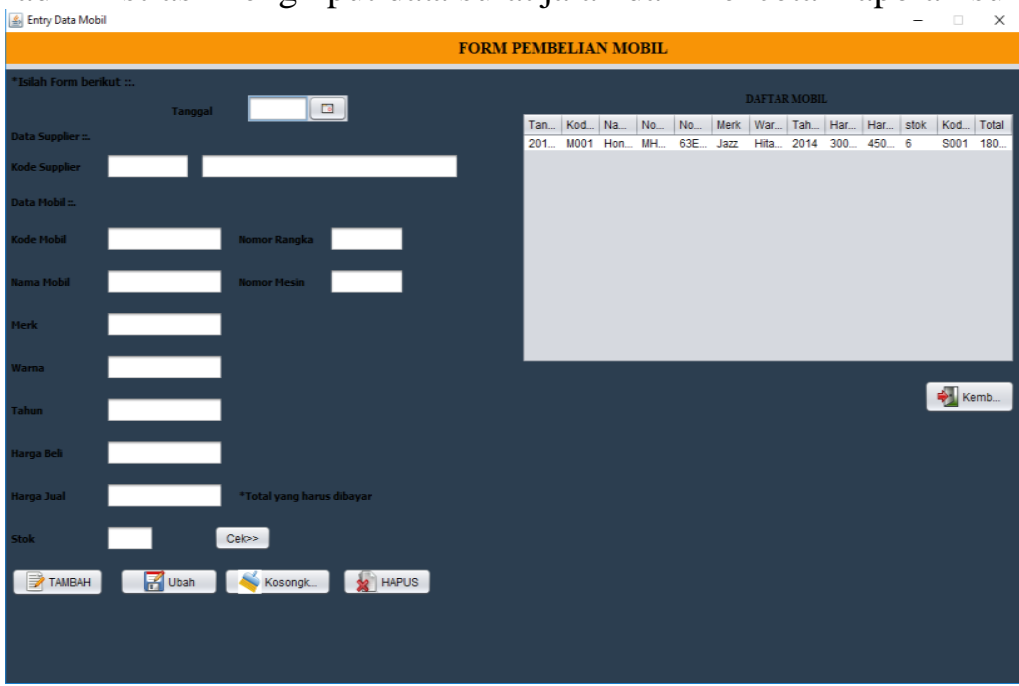

Gambar 6. Tampilan Pembelian

Form ini bagian administrasi menginput data pembelian mobil atau penambahan stok dari supplier.

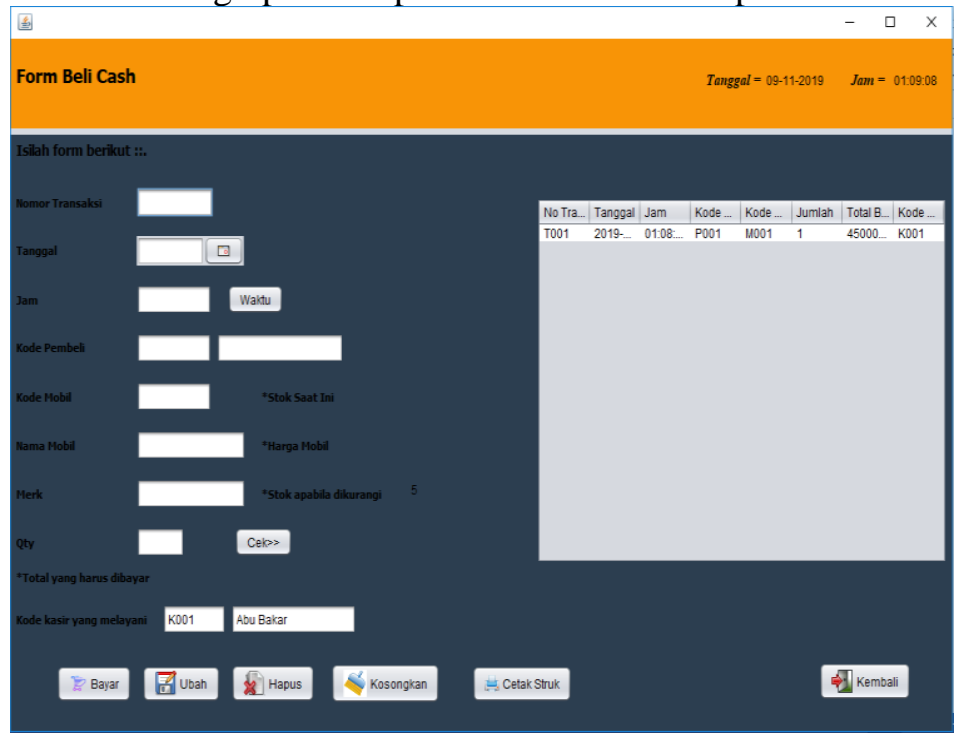

Gambar 7. Tampilan Penjualan Tunai 
Form ini bagian administrasi menginput data penjualan tunai dan mencetak struk untuk diberikan kepada pelanggan.

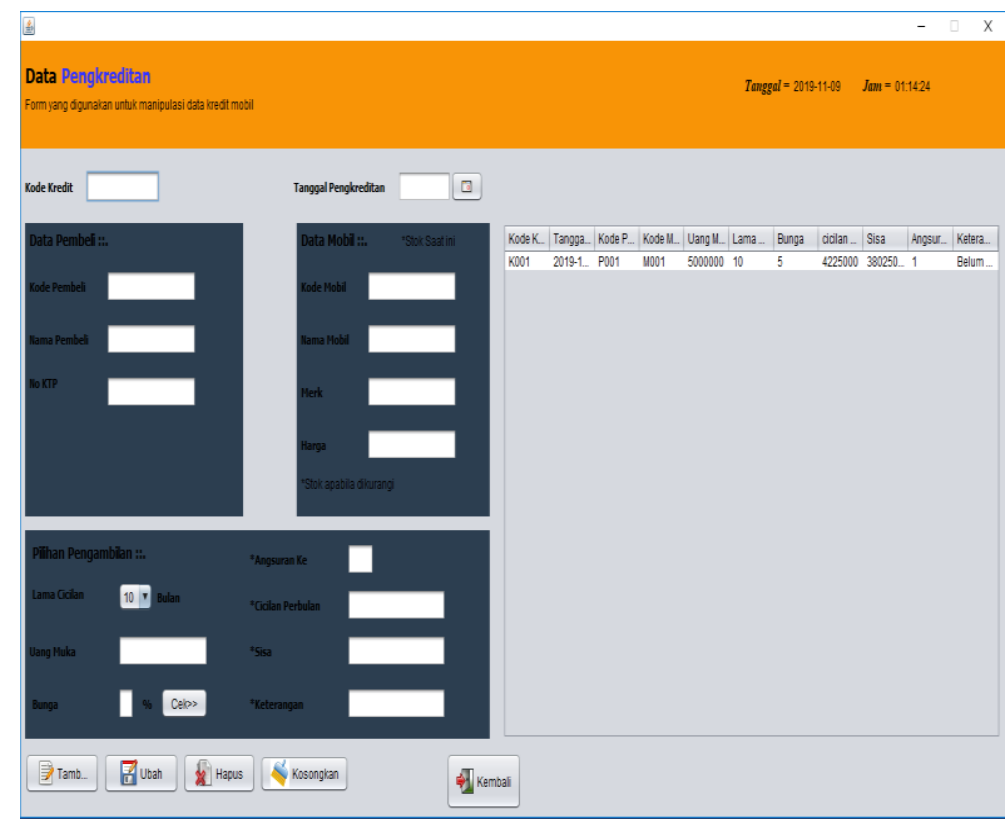

Gambar 8. Tampilan Penjualan Kredit

Form ini bagian administrasi menginput data penjualan kredit untuk bisa melanjutkan ke proses pembayaran cicilan.

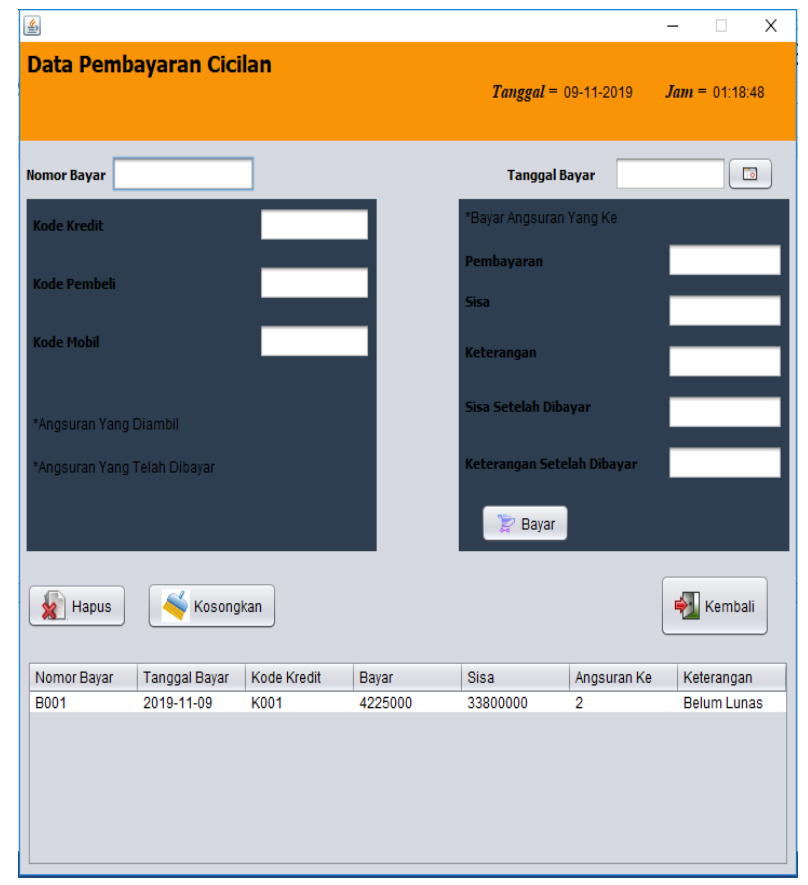

Gambar 9. Tampilan Pembayaran Cicilan

Form ini berfungsi untuk melakukan penginputan data pembayaran cicilan yang akan dilakukan oleh bagian administrasi. 


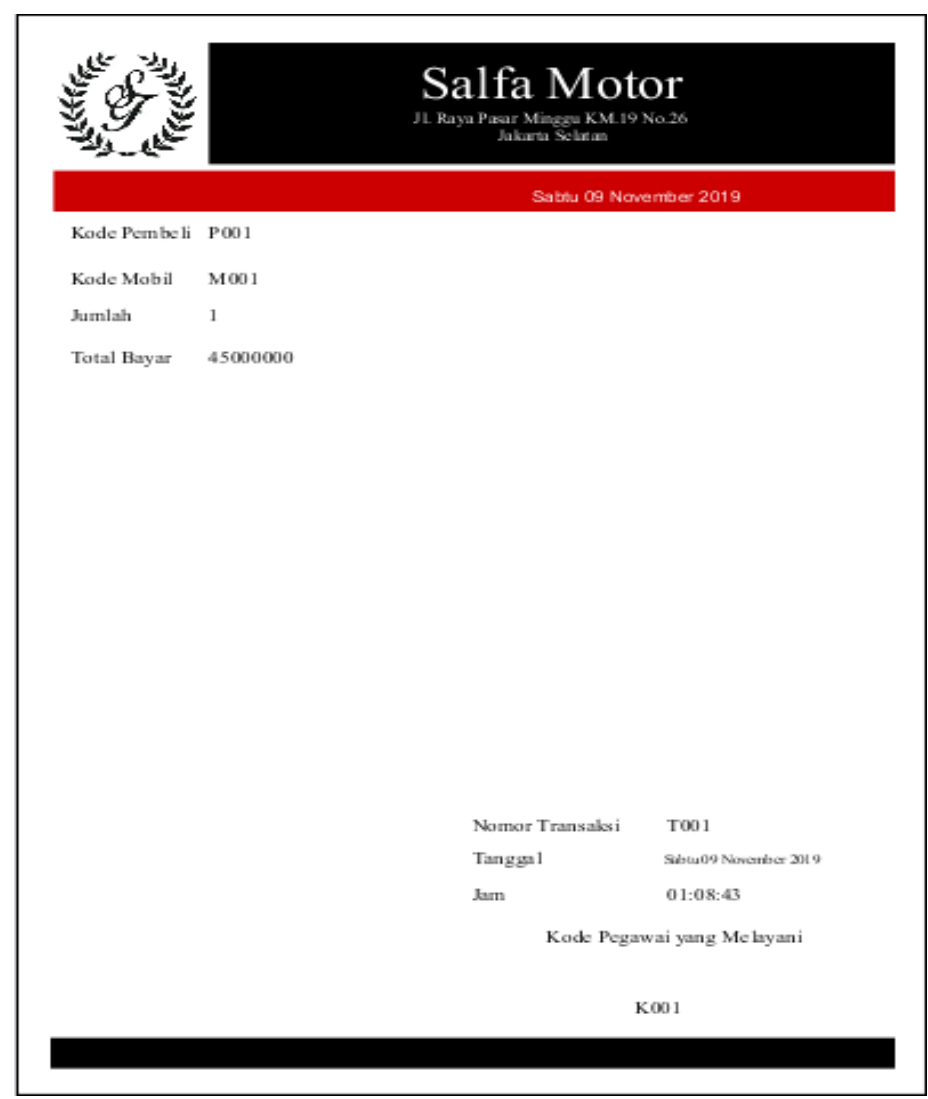

Gambar 10. Tampilan Nota Pembayaran

Nota pembayaran ini dapat dilakukan setelah kita menekan button cetak struk pada form penjualan tunai.

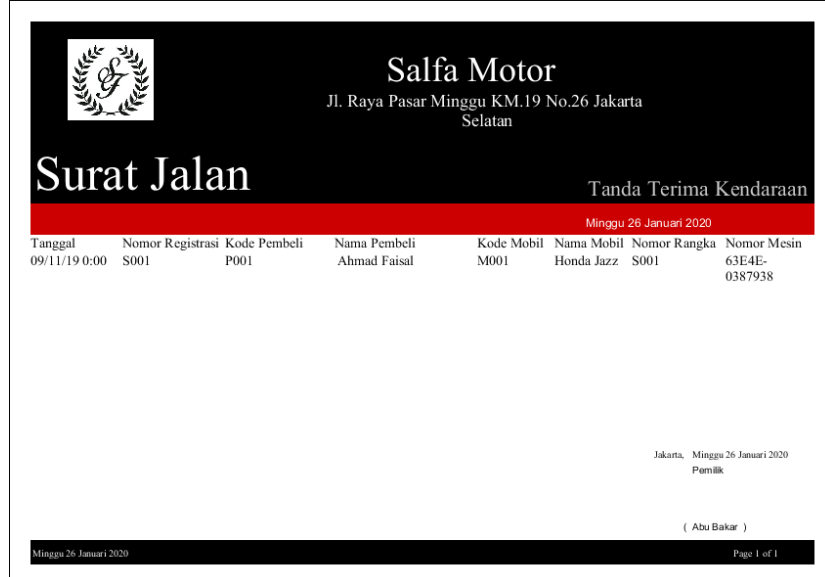

Gambar 11. Tampilan Laporan Surat Jalan

Rekap laporan surat jalan ini dapat dilakukan setelah menekan button cetak pada form surat jalan. 


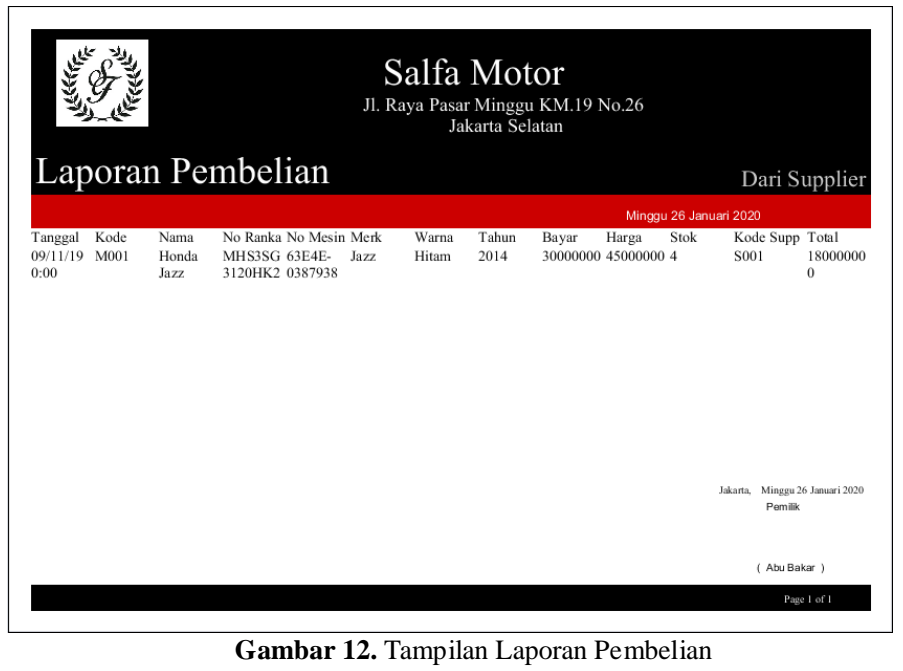

Rekap laporan pembelian ini dapat dilakukan setelah menekan button cetak pada form daftar data mobil.

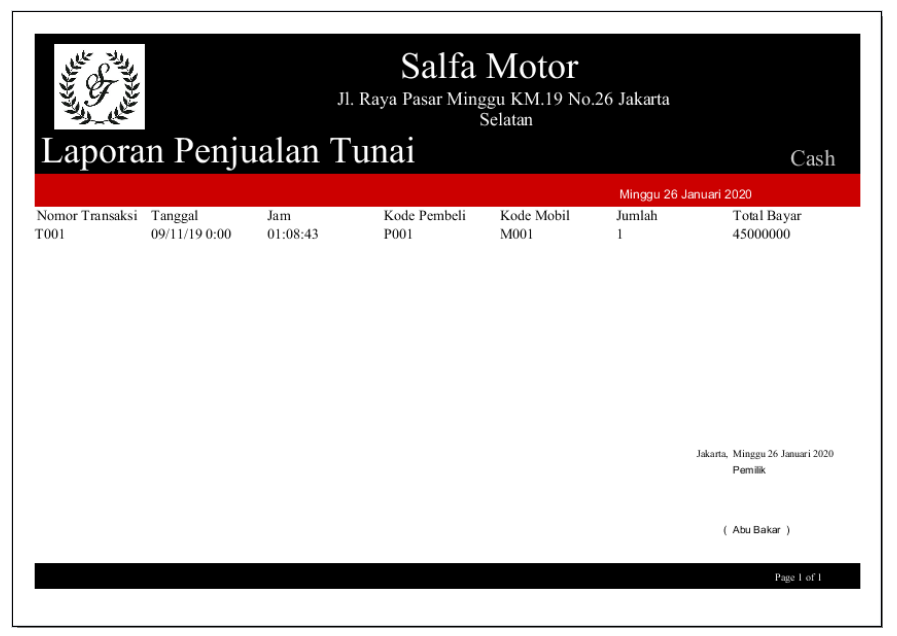

Gambar 13. Tampilan Laporan Penjualan Tunai

Rekap laporan penjualan tunai ini dapat dilakukan setelah menekan button cetak pada form daftar transaksi cash.

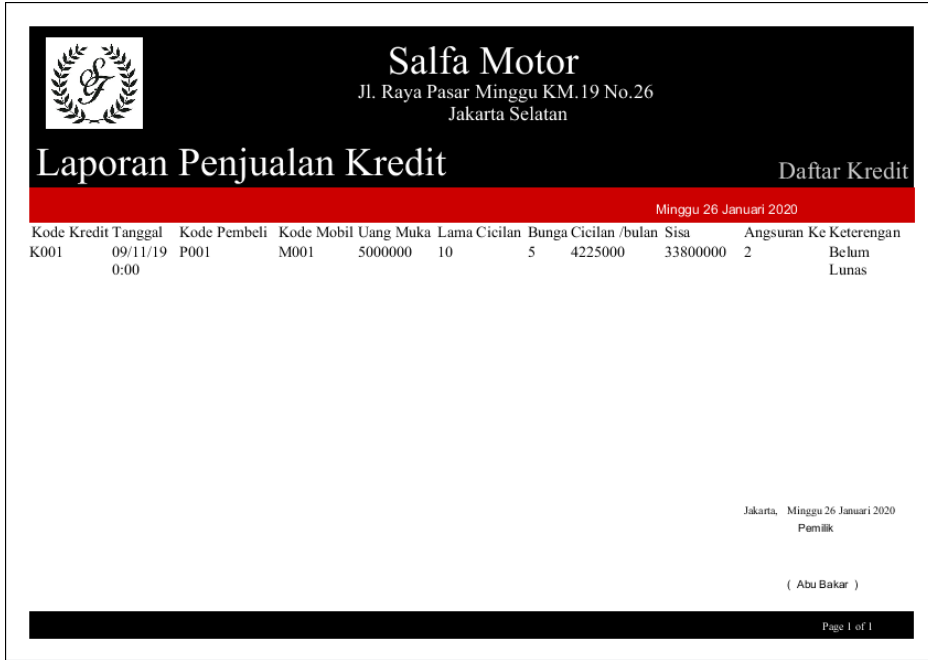

Gambar 14. Tampilan Laporan Penjualan Kredit 
Rekap laporan penjualan kredit ini dapat dilakukan setelah menekan button cetak pada form daftar data kredit.

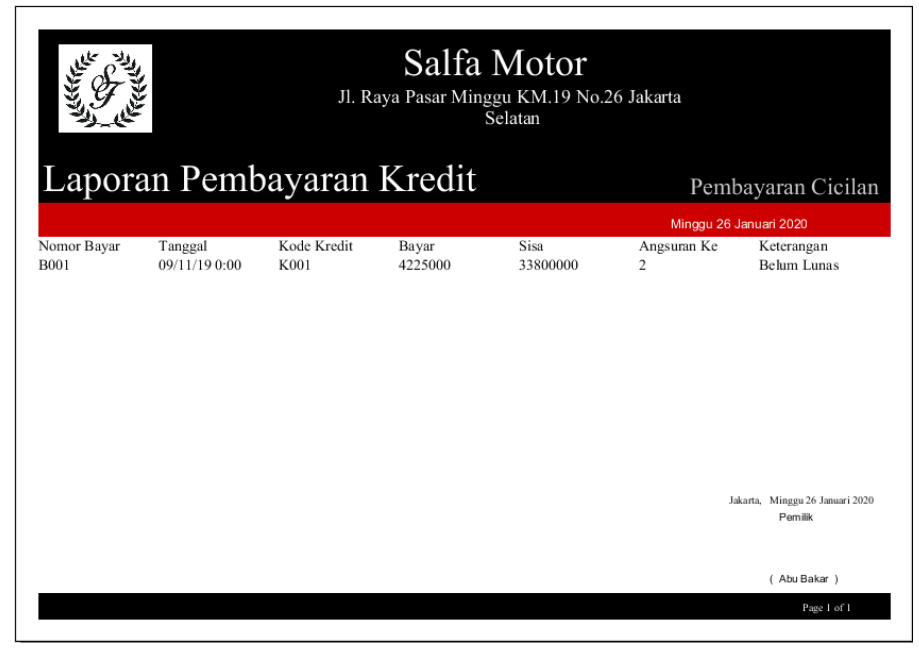

Gambar 15. Tampilan Laporan Pembayaran Cicilan

Rekap laporan pembayaran cicilan ini dapat dilakukan setelah menekan button cetak pada form daftar data pembayaran cicilan.

\section{SIMPULAN}

Berdasarkan hasil analisis dan perancangan yang peneliti lakukan, maka dapat ditarik kesimpulan sebagai berikut :

1. Untuk merancang sebuah aplikasi yang dapat mempermudah dan mengamankan proses pengolahan data penjualan dan pembelian salfa motor yang berbasis desktop yang dapat menampilkan , menambahkan, serta memanipulasi data pembeli, mobil, supplier, pembelian, penjualan tunai, penjualan kredit, pembayaran cicilan, serta surat jalan.

2. Perancangan aplikasi penjualan dan pembelian mobil salfa motor dirancang berbasis desktop menggunakan java netbeans 8.2 dengan bahasa pemograman java dan MySQL sebagai database Management Service.

3. Dengan dibuatnya sistem yang terkomputerisasi dapat mempermudah dalam pencatatan data penjualan dan pembelian dengan menyimpan ke dalam database serta dapat memudahkan karyawan pada salfa motor dalam mencari informasi mengenai data tersebut.

Dengan adanya aplikasi program ini diharapkan dapat mempermudah dalam pengolahan ataupun pengadaan sistem data yang ada di salfa motor secara komputerisasi.

\section{DAFTAR PUSTAKA}

Alamsyah. (2011). SISTEM INFORMASI PENJUALAN TIKET PO . METRO EXPRESS. Jurnal Ilmiah Foristek, 1(2), 64-69.

Deddy, A., \& Sherin, N. (2017). Perancangan Sistem Informasi Penjualan Mobil Di Dealer Lung Ma Motor. Jurnal Algoritma, 14(2), 305-313.

Februariyanti, H. (2012). Rancang Bangun Sistem Perpustakaan untuk Jurnal Elektronik. Jurnal TEknologi Informasi DINAMIK, 17(2), 124-132.

Yunaestri, D. A. (2011). Sistem Informasi Jadwal Keberangkatan Bus dan Retribusi Terminal Kabupaten Pacitan. Journal Speed, 3(1), 1-7. 